\title{
The Diversities of the Competitive Advantage Concepts and Understanding Sourced by Resource-Based Approach to Firm
}

\author{
Pinar Başar ${ }^{1}$ \\ ${ }^{1}$ Department of Business Administration, Istanbul Commerce University, Turkey \\ Correspondence: Pinar Başar, Department of Business Administration, Istanbul Commerce University, Turkey. \\ E-mail:pbasar@ticaret.du.tr
}

Received: March 6, 2015

Accepted: March 24, 2015

Online Published: April 20, 2015

doi:10.5539/ijbm.v10n5p113

URL: http://dx.doi.org/10.5539/ijbm.v10n5p113

\begin{abstract}
Aim of the study is to investigate the diversities of competitive advantage concepts and how those companies use their sources to provide sustainability and competitive advantage. Competitive advantage; in the information age, intends to aim at inclining to skills and abilities not easily imitated by competitors in order to capture competitive advantage. A semi-structured interview is conducted with three companies. This research allows the classification of resources by industry profile and can demonstrate differences in that profile. The findings show that intangible resources gains prominence as a competitive advantage and have more impact on performance in many companies as mentioned in other studies. A construction company, a food company and an automotive company are examined. The competitive environment pushes the companies to be innovative and to show corporate image in ways like social responsibility, where the know-how and intellectual property is one of the most important way for sustainability. Know - how and experience create deliver tangible results. The learning opportunities engage employees and reinforce company culture, where the companies operate in an environment where new technologies replace many core functions.
\end{abstract}

Keywords: the diversity of the resource-based approach, competitive advantage

\section{Introduction}

\subsection{The Literature Review of the Resource-Based View}

The Resource-Based View has set out with the capabilities and the differentiation from each other according to the talent theory (Penrose, 1952, p. 805) and following the discussion of the resource assignment problem based on the efficiency and the firm size is based on the profit-pursuing (Penrose, 1955, pp. 531-532). On the competitive advantage of the concept of products and production contributions follow a period discussed by the company. But the subject has become the area of interest of strategic business administration, which resources are required (Wernerfelt, 1984, p. 531).

The possession of the necessary resources issues have become interesting topics in the strategic business management in periods where contributions to a competitive advantage to product and production concept are relatively discussed by the company (Wernerfelt, 1984, p. 531).

A discussion on topics related to claiming of organizational culture is a rare and valuable in that inimitable competitive advantage source (Barney, 1986a, p. 663) and competition on strategic factor markets, (Barney, 1986b, pp. 1232-1233) can be considered as the settled period of the resource-based view. Resource-Based Theory of the Firm, also points to the impact of organizational culture and politics of the organizational context of the adoption of the strategic resources to provide competitive advantage to the organization (Deliorman \& Spring, 2009, p. 30).

Strength-Opportunity (internal analysis) Opportunities-Threats (external analysis-environmental analysis) (Learned, Christensen, Andrews, \& Guth, 1965; Barney, 1991, p. 105) and Positioning Model which is described in Porter's 5-forces model developed in the 1980s, accepts the perimeter of the company as a starting point of the strategy, (5 Basic Power Concept at Competition (a) the Power of Suppliers (b) The Power of buyers (c) the Threat of Substitutional Goods, (d) New Entrants Threat and (e) the Intensity of Competition). Thus, this is called the angle of view from outside to inside and the company should accordingly seek the most favorable strategic position among its surroundings (Porter, 2008, p. 80). According to the Porter's competitive model; the 
structure of the industry will determine the competitive situation in the industry. Five power will determine the average profitability of the industry. In turn, five power will affect the profitability of the company's strategy. The source of ideas for this model; (a) some industry and strategies are more profitable than others, (b) selecting the right industry with this cause and positioning the most attractive place in the industry bring competitive advantage (c) create bargaining power and mobility barriers as fundamental competitive tool (Bakoğlu, 2003, p. $66)$.

Boston Consulting Group (BDG) (Bakoğlu, 2003, p. 73), the Ansoff matrix and SWOT (Strength, Weakness/Limitations, Opportunity and Threat) analysis (Valentin, 2001, p. 54), PESTEL (Political, Economic, Social, Technological, Environmental, Legal) analysis (Walsh, 2005, p. 115) also counted among other strategy models based on the traditional competitive advantage.

Due to inadequacy of Porter's approach, researches have been conducted of the impacts of the company resources on performance with different effects not only for companies in the same sector but also companies working in the same group (Barney Clark, 2007, p. 3). In this context, there have been several researches that attempt to establish new theories. These researches include the researches that examined the strategic membership in the group by sector and the relationship between performance of the firms (Cool \& Schendel, 1988, pp. 219-221) and the researches examining the realization of the sustainable economic benefits of source markets and their impacts (Amit \& Schoemaker, 1993, pp. 43-44) as examples. Thus, the number of researches focusing on in-house resources has increased and a new period of the validity of multiple perspectives rather than accepting Resource-Based Opinion as a theoretical basis with well-defined borders has emerged.

\subsection{The Resource-Based Theory of the Firm}

Prahalad and Hamel (1990, p. 79) made a very important contribution on competitive advantage and understanding by developing basic skills argument.

Basic ability argument, forms the basis for the analysis of dimensions of Strength and Weakness in part of the internal analysis of SWOT analysis and Resource-Based Vision (Barney Clark, 2007, pp. 49-50; Barney, 1991, p. 100). On Hamel and Prahalad's competition argument (1990, p. 80), which is based on basic competence (competence) and ability (capability), the company is seen as portfolio of talents. The authors have played an important role in the creation of the Based Theory of the Firm (or Dynamic Capabilities Based Theory of the Firm's) by basing on the source of the economist Schumpeter (Bakoğlu, 2010, p. 246). Lately the Resource-Based Theory of the Firm is combined by integrating internal analysis and external analysis (Collis \& Montgomery, 1995; p. 119). Basic Skills argument, for making changes in the perspective of strategic management thinking can be considered as the anniversary of the modern strategic management thinking (Bakoğlu, 2010, p. 27).

Prahalad and Hamel (1994, pp. 7-9) suggest that today's industry experienced a paradigm shift as shown in the figure below. 


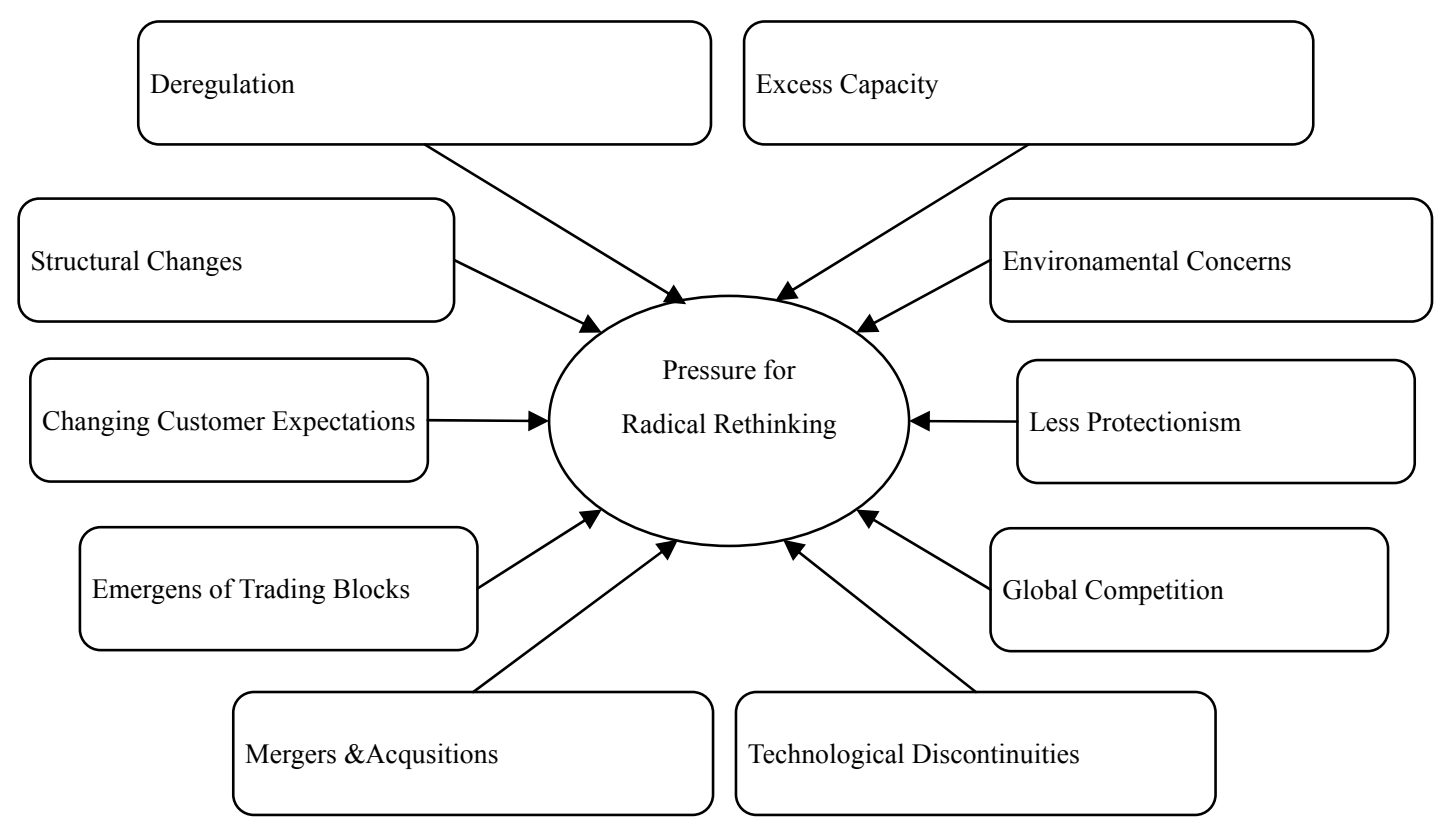

Figure 1 . The inevitability of industry transformation

Source: Prahalad, C. K. and Hamel, Gary (1994).

All these factors may be kept on agenda for constantly and dynamically making innovations by questioning the conventional methods and reconsidering generally accepted assumptions and understandings (Bakoğlu, 2003, p. 73). According to the Resource-based view innovation is a never-ending process. (Aşkun \& Bakoğlu, 2010, p. 114).

The competitive advantage value of a resource or a capability is claimed to be determined by the dynamic interaction of three fundamental market forces as shown at diagram below (Collis \& Montgomery, 1995; p. 120). 


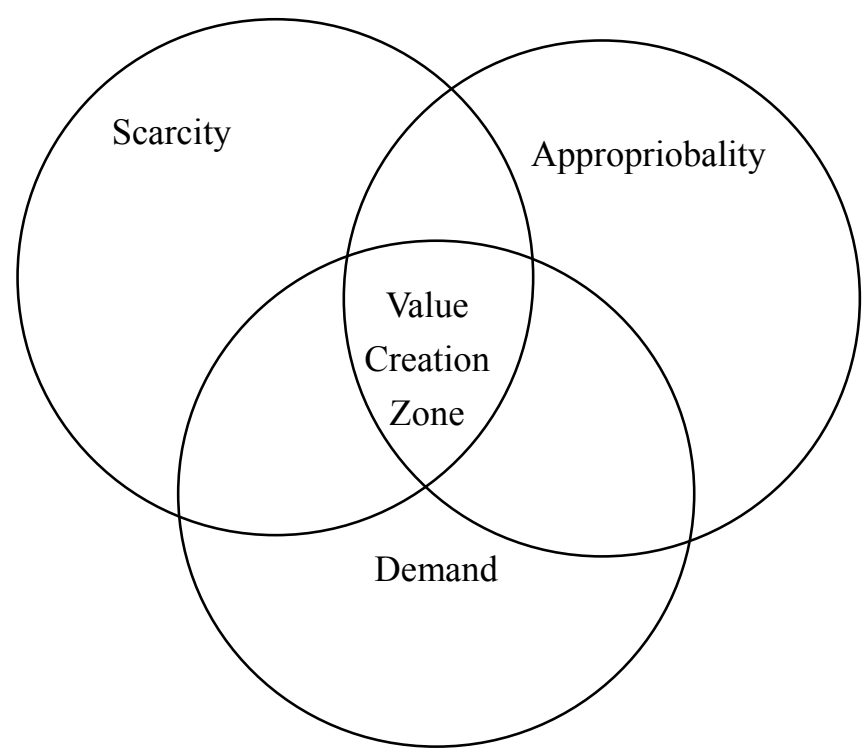

Figure 2. The value of a competitive resource or a capability formed by the dynamic interaction of three

fundamental market forces

Resource: Collis, David J. and Montgomery, Cynthia A. (1995).

The features can be seen by the diagram above, (a) Scarcity (can be imitated or substituted? and reliable?) (b) Appropriability (who gains the profit?) and (c) Demand (can a resource or a capability satisfy the clients demands? and is it competitively advantageous?). The sustainable competitive advantage is based on the creation of the source are strategically not equally substituted, valuable, rare, imperfectly imitable according to The Resource-Based Firm Theory (Barney, 1991, pp. 105-112). This situation indicates possessing superior resources and creating imitating obstacles are the basic tools on competitive advantage according to resource-based theory of firms (Bakoğlu, 2003, p. 68).

There is a fundamental difference between the sources and capabilities. Whereas resources are inputs into the production process and fundamental analysis units; capabilities include capital equipment elements, patents, trademarks, assets such as finance. The production activities require the coordination and cooperation of the resource groups but very few resources are productive. Capability is the ability to perform certain tasks or activities as a team. According to Resource-Based Theory of Firms, resources determine the firm's capability and firm's capability determines the competitive advantage (Bakoğlu, 2010, p. 252). The following figure shows the conversion of source to capability then to the competitive advantage and then the strategy. 
1. Investigate the surrounding especially surrounding of the industry.

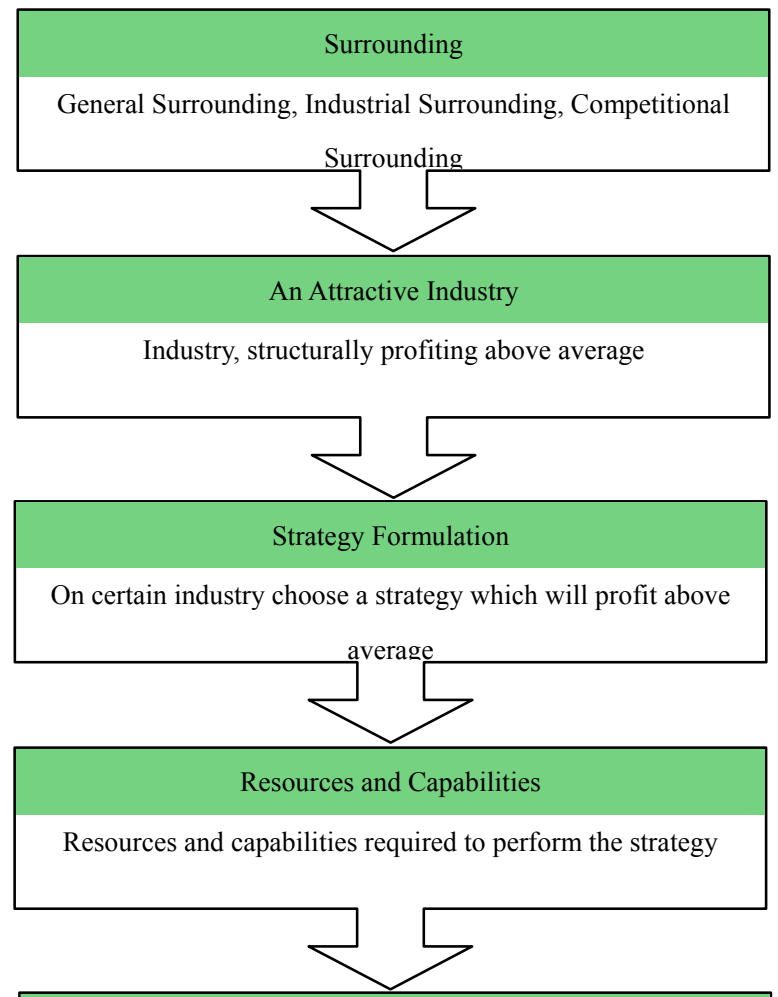

5. Use the strength of the firm to perform the strategy.

\section{Executing Strategy}

Choosing strategic actions to perform the strategy effectively

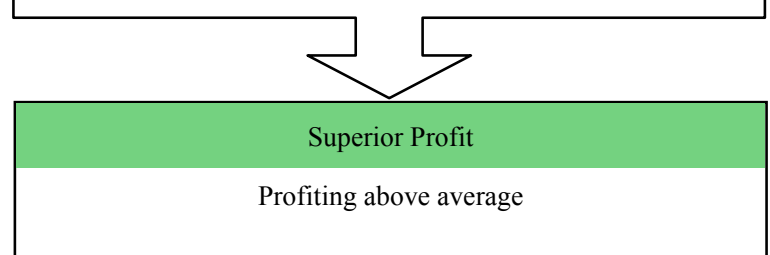

Figure 3. Obtaining above average by income according to the industrial economics model Resource: Hitt, M.A., Ireland, R.D. and Hoskisson, R.E., (2005).

Markets and resources views have created two different opinions on strategy development. 
1. Determine the resources of firm. Examine the strengths and weaknesses compared to its competitors.

2. Determine the capacity of the firm. Determine which proficiencies are superior than the competitors.

3. For competitive advantage, determine the firm's potential resources and capabilities.

4. Position in an attractive industry.

5. Profiting above average.

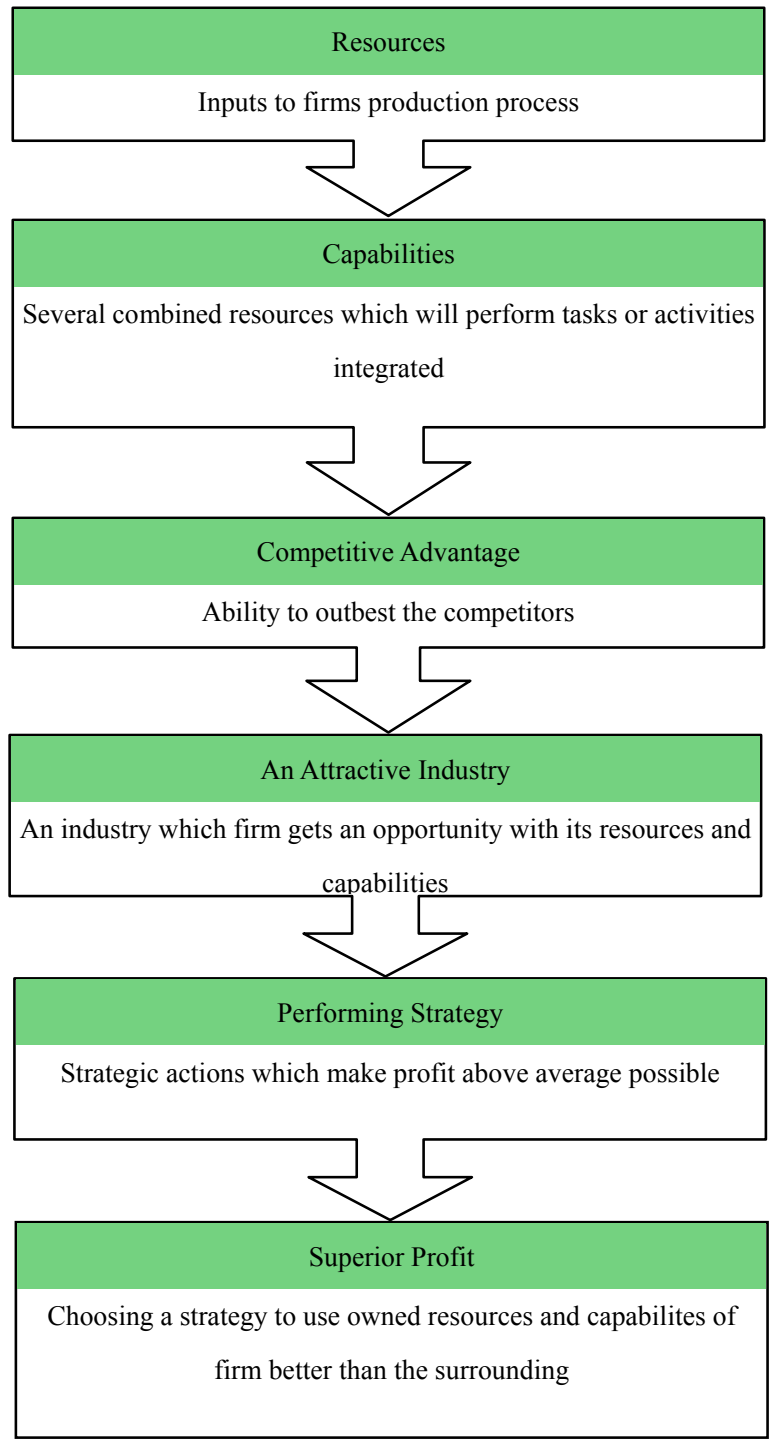

Figure 4. Obtaining above average by income according to the resource-based model 


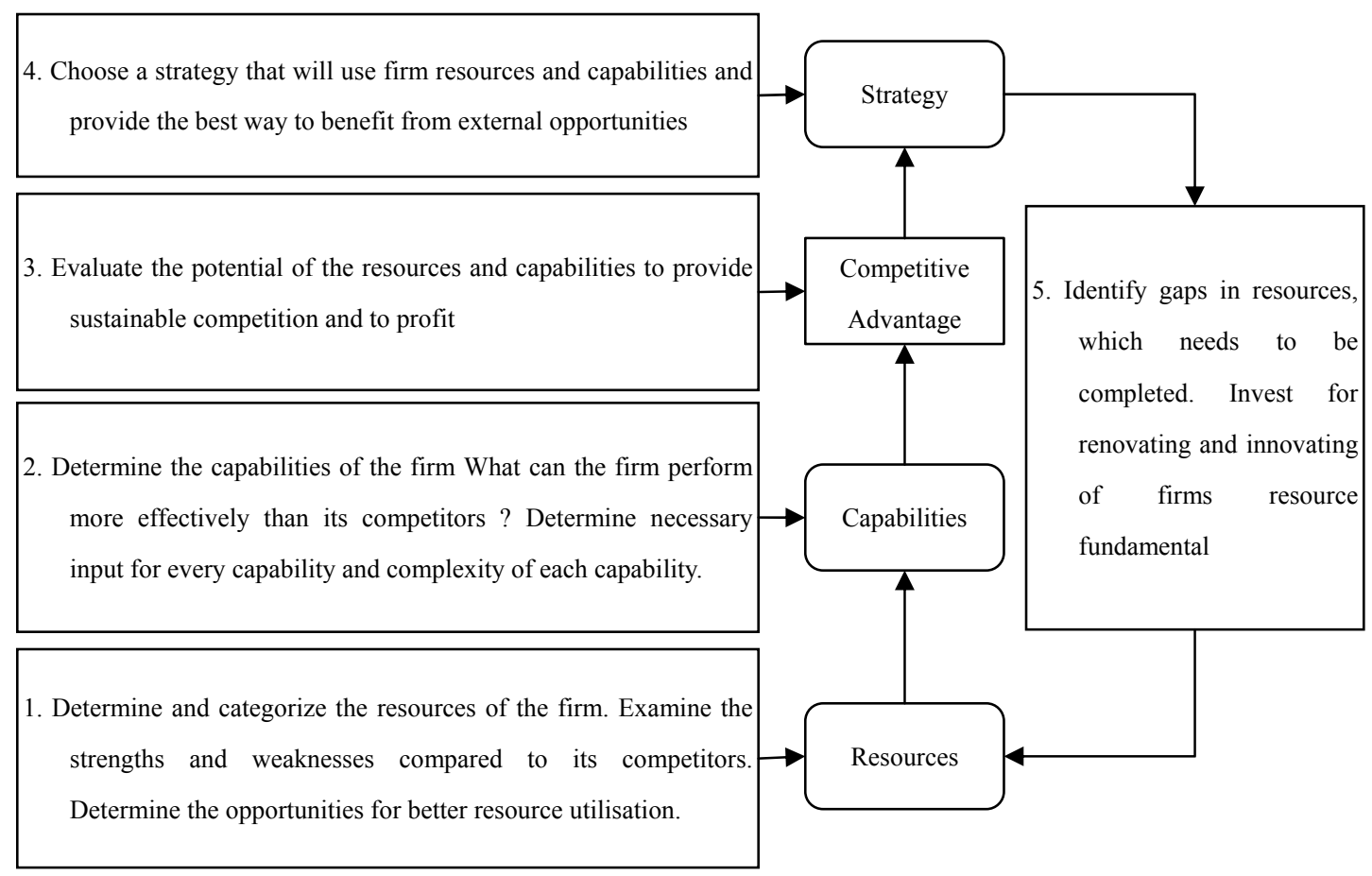

Figure 5. Resource-Based theory of the firm competitive advantage: implementation of the strategy formulation

Resource: Grant, Robert M (1991).

Resources can be examined in six general categories: (a) financial resources, (b) physical resources, (c) human resources, (d) technological resources and (e) fame (reputation), (f) organizational resources (Bakoğlu, 2010, p. 252).

The most important skills for the majority of companies consist of the integration of individual functional ability. Capabilities consist of complex coordination among people and between people and resources. Organizational routines concept helps to explain the relationships of resources, capabilities and competitive advantage: (a) the relationship between the source and capabilities, (b) the relationship between efficacy and flexibility (capability for individuals, routine for the organization), (c) Experience of the economy and (d) the complexity of capabilities (Bakoğlu, 2010, pp. 253-254). According to Resources Based Firm Theory, necessary features of capabilities and resources for a sustainable competition are (Grant, 1991, pp. 124-128): (a) durability, (b) transparency, (c) transfer and (d) inimitability.

One of the comparisons approach with the traditional strategy of industrial organization economics and Resource-Based Theory of Firm has been made by Schneider and Lieb (2004, p. 174). According to them, the source of competitive advantage is; market entry barriers for strategy which traditionally sees companies' homogeneous and organizational capabilities for resource-based view which sees firms heterogeneous. The comparative summary of traditional concept of competitive advantage and Resource Based Theory of the Firm is given in the table below. Resource-Based Theory of the Firm moves from differences arising from individual privacy of each company and the company's resources and capabilities. This view emphasizes the power to influence the environment and the internal dynamics of the company. According to Resource-Based Theory of the Firm, firms are not homogeneous and heterogeneous environment can produce different answers to the internal dynamics (Bakoğlu, 2004, p. 166). 
Table 1. The differences guide to the resource-based approach of firm to the competitive advantage concepts and understanding

\begin{tabular}{|c|c|c|}
\hline & $\begin{array}{l}\text { Traditional } \\
\text { Understanding }\end{array}$ & $\begin{array}{l}\text { Competition According to Resource-Based Approach of the } \\
\text { Firm }\end{array}$ \\
\hline $\begin{array}{l}\text { Basic Orientation Points } \\
\text { in Competition }\end{array}$ & Products, Market, Industry & Resources, Capabilities, Capacities, Processes, Information \\
\hline Focus points at & Position & Innovation \\
\hline Competition Approach & Domination & \\
\hline $\begin{array}{l}\text { Priorities on Competition } \\
\text { Approach }\end{array}$ & Capturing the competitive advantage & Sustaining the competitive advantage \\
\hline $\begin{array}{l}\text { Innovation and Creativity } \\
\text { Understandings at } \\
\text { Competition }\end{array}$ & $\begin{array}{l}\text { Positioning on profitable sector and } \\
\text { changing the structure of the industry }\end{array}$ & $\begin{array}{l}\text { New routines, capabilities and improving organizational abilities, } \\
\text { changing or have potential of changing the rules of competition in } \\
\text { industry (making the right combination of resources and suitable } \\
\text { capability) }\end{array}$ \\
\hline Direction of the Effect & Outside- in & Inside-out \\
\hline $\begin{array}{l}\text { Improving } \quad \text { Strategy } \\
\text { Understanding }\end{array}$ & Strategic Conformity & Strategic expansion \\
\hline $\begin{array}{l}\text { Starting Point on } \\
\text { Management Strategy }\end{array}$ & Market/ Industry structure & Firm's resources and internal structure \\
\hline $\begin{array}{l}\text { Competition Weapon on } \\
\text { Management Strategy }\end{array}$ & Bargaining Power and mobility obstacle & Superior resources and imitation obstacles \\
\hline $\begin{array}{l}\text { Emphasis on Firm } \\
\text { Strategy }\end{array}$ & $\begin{array}{l}\text { Sum of profitable and cash producing } \\
\text { portfolios at different sectors }\end{array}$ & Creating value/synergy between related sectors \\
\hline $\begin{array}{l}\text { Business Departments and } \\
\text { Coordination }\end{array}$ & $\begin{array}{l}\text { Highly independent (autonomy), } \\
\text { coordination on level }\end{array}$ & Highly integrated (interactive), coordination on high level \\
\hline $\begin{array}{l}\text { Assumptions } \quad \text { for } \\
\text { Surroundings }\end{array}$ & Predictable, slowly varied & Unpredictable, dynamic \\
\hline Assumptions for Firm & $\begin{array}{l}\text { Firms are actors to capture or organize } \\
\text { necessary resources to capture } \\
\text { opportunities around its surroundings }\end{array}$ & $\begin{array}{l}\text { Firms are different from each other (resources and capabilities } \\
\text { distributed heterogeneous among firms) and compete on the basis } \\
\text { of these differences }\end{array}$ \\
\hline
\end{tabular}

Resource: Bakoğlu, Refika (2003).

According to the Traditional Understanding of Competition Supply Company Based Approach.

In Resource-based theory of the firm, different from the traditional competitive advantage, strategy of the firm discovers that business areas are related to create value and making strategic investments for the structures of the traditional business units and functions to operate integrally and processes become more important than the products and markets. (Collis \& Montgomery, 1995; Stalk, Evans, \& Shulman, 1992; Bakoğlu, 2003, p. 70).

Traditional understanding of strategy development based on strategic alignment (strategic fit) accepts 'outside-in' effect approach; whereas; Resource-Based Firm Theory accepts "inside-out" effect approach based on the strategic approach stretch (Bakoğlu, 2003, pp. 69-70). 


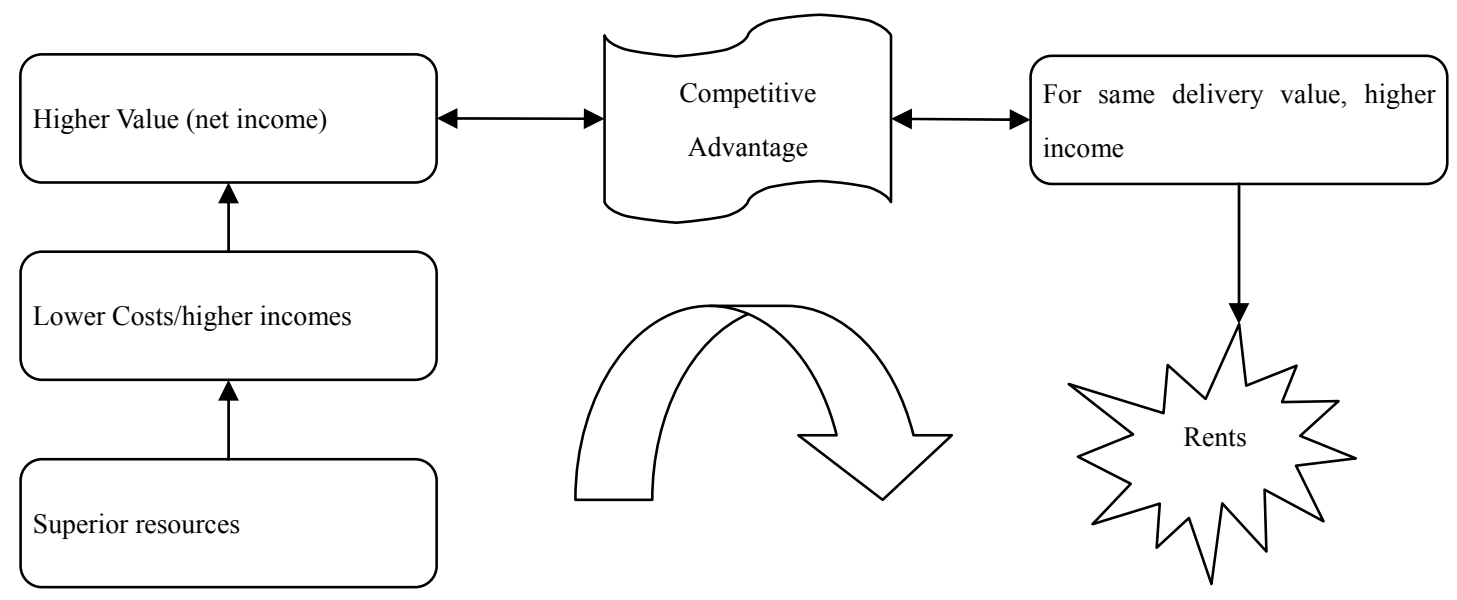

Figure 6. The logical chain from source to rent

Resource: Barney, Jay B. and Clark, Delwyn N. (2007).

Economic rent is a factor which is the excess of the opportunity cost (source) (Barney Clark, 2007, p. 28). Another important assumption of Resource-Based Theory of the Firm, which also accepts sustainable competition as an assumption, focuses on increasing costs for source of the "economic rent" (Barney, 1986b; Connor, 1991; Bakoğlu, 2003, p. 70).

Accepting the approach of classification of business capabilities according to the business functions resource-based management capabilities are divided in categories. The size of the business management capabilities are determined as production, marketing and sales, information systems, learning, logistics and establishing partnerships (Acer \& Poison, 2008, p. 109)

The central criteria of Resource-Based Theory of the Firm is sustainable competitive advantage (sustained competitive advantage) are determined from two basic characteristics like (a) the durability and currency of the resources and proficiency (b) imitability. Imitation consists of three criteria which are (a) the speed of seen by other firms (transparency), (b) transferability of the resources and capabilities by competitors (transferability) and (c) the ability to imitate resources and capabilities of firm by other companies (replicability), (Wheel \& Hunger, quoted from 2000; Bakoğlu, 2003, pp. 70-72).

Resource-Based Theory of the Firm shifted the competitive advantage concept by focusing on resources and capabilities that cannot be easily imitated by competitors. The question is changed from where the competition will be to how the competition will be (Bakoğlu \& Yilmaz, 2005, p. 85).

\section{Methodology}

This qualitative research is chosen to have a flexible and fluid structure because of the lack of time of interviewees, which are in management positions and the variability of the industry. The aim is to ensure flexibility in exploring the resources of different particular areas and to develop with different interviewees. The interview can be shaped by the interviewee's own understandings as well as the researcher's interests. The primary benefit of a semi-structured process is the flexibility it allows relative to the more formal structured interview. This enables understand managers' useful insights into the experiences and thoughts, which is especially helpful in comparing industries.

\subsection{The Construction Company}

The Construction Company is a large and powerful company which has more than 10,000 employees. Generally performing works on certain country, in Turkmenistan but lately it's widening its activity perimeter and started to perform works on Kazakhstan and Russia. Their general advantage from other global construction companies is their headquarters location. This maintains better and more frequent interaction with local authorities and settled manpower which brings mobility and makes easier to take action even for harder tasks which distinct the company from its competitors. Increase in experience and completed works also creates an increase in trust to their company and provide a good attachment to local authorities.

Approximately $\% 10$ of the employees is white-collared employees and generally well-experienced on their field and on special requirements/ regulations of Turkmenistan. Even though they have more attractive working 
standards than their competitors; they try to maintain even better standards for their employees for them to continue to work with them. They have two HQ s in Ashgabat and in Istanbul, which Ashgabat HQ is the main HQ. In both HQ they have more than 500 staff and more than $\% 30$ of their staff has been working more than 5 years with us who are very effective for coordination between different departments and business units. The organization culture, which is created with experienced employees; shortens the adaptation period of new beginners and increase the productivity of staff. The company still invests for developing working experience to make sure that culture can sustain with their newcomers.

They increased the number and capacity of their completed works throughout the years and now all suppliers and subcontractors are willing to work with us which brings an obvious advantage in contracting. In contracts the company can almost determine all conditions and standards for their advantage. Sometimes with their business partners whom they have worked together for many years, we even determine all the prices and conditions.

Strong financial capability makes strategic alliances unnecessary. The connections and the former work strengthen the company reputation in the country. It facilitates to continue to work in that country and attracts good employee to the company. The architects and other employees are experienced and have know-how, which is very important as competitive advantage.

Project time limits enforce the teamwork and necessitate organizational citizenship behavior. The knowledge share is often in meetings.

\subsection{Food Company}

The most important competitive advantage of the food company is innovativeness. Organization facilitates to share ideas and knowledge. The success of global marketing strategy ant the ability to develop international strategies is high. The company locates its production in different countries.

Managers have the capability of creating and routing vision. They have the ability of strategic planning and making changes in their operating environment.

The quality of their products is high. The Dairy products necessary work is done to maintain the fresh collected from the nearest channel. Manufacturing process can be adapted to new ideas and production methods. The level of information about the technical aspects of their operations managers is high.

The marketing and sales staffs have high marketing and sales skills and keep the highest level of the work by training. The impact of the price guarantee of their system is high. Information Systems Capabilities benefit to get the information, analysis and knowledge. The use of information systems and electronic data interchange for operating and financial results of using information systems their reporting capability. The ability to cope with internal and external difficulties and explore the surrounding opportunities is high by useful ideas in a field, experience, knowledge and practices by transferring from other areas and from the past experiences.

Distribution channels are large and effective. Logistics services are differentiated according to the customer needs. Frequent Market research allows the company to have ability to react or satisfy customer needs.

Long-term relationships are established by customers and suppliers partnership-building capability. By the establishment of the partnerships all the benefits and risks of the activities which can occur are cleared with contracts. The international investments and to gain new brand by strategic partnerships are important.

\subsection{Automotive Manufacturing Company}

This company aims for world class manufacturing in automotive industry. Their basic skills are lean production and people oriented management. Their corporate vision is to be a company which shapes the customer expectations and to be proud of. They aim to present the product and services which satisfies the society's need for mobility and increase the life quality. The factory is 1 million $\mathrm{m} 2$ wide with $350.000 \mathrm{~m} 2$ closed area. The production capacity is 400.000 . They have more than 6000 people working both white and blue collar.

They believe in investing in people and the innovation potential of them. They invest $\% 3$ of their turnover in to $\mathrm{R} \& \mathrm{D}$, a ratio above international average. The company also cares for patent studies. 145 patents have been obtained in the last four years. They give lean production and labor safety the utmost importance. They aim for zero work incident and creation of a work safety policy in order to reach that goal. They follow up certain standards in the way they work and have themselves quality checked by an independent auditing firm. Last year their company was rewarded to be a "Gold Factory", a reward few factories could achieve within similar factories in Europe which gave us leverage in competition within global markets

Their financial performance has been solid with one of the highest EBITDA (Earnings before interest depreciation amortization) ratio within market and ongoing net profits. The company has been fueling the market with 
innovative products for years. As well as feeding the segments with different products their company has also created a mid- segment by producing unique commercial products which become a revolutionary success in automotive market.

The corporate message to society is "to grow with their country ". Following this philosophy they focus on education, cultural activities and environment by investing in social responsibility projects.

The resources are classified in amany researches in different ways. Mills, J., Platts, K., \& Bourne, M. (2003, p. 155) suggest as company resources tangible resources, knowledge resources, skills and experience; system and procedural resources, cultural resources and values, network resources, resources with potential dynamic capability. Acar and Zehir (2007) aligns the resources as management capabilities, production capabilities, marketing and sales capabilities, information systems capabilities, leaning capabilities, logistic capabilities and partnership building. In this study, the capabilities and resources are summarized as in the table below:

\begin{tabular}{llll}
\hline The Resources and the capabilities & $\begin{array}{l}\text { Construction } \\
\text { Company }\end{array}$ & Food company & $\begin{array}{l}\text { Automotive } \\
\text { Company }\end{array}$ \\
\hline Management Capabilities & 1 & 2 & 3 \\
Production Capabilities & 1 & 2 & 2 \\
Marketing and Sales Capabilities & & 1 & 1 \\
Information Systems Capabilities & 2 & 1 & 1 \\
Leaning capabilities & 1 & 2 & \\
Partnership Building & 3 & 1 & 2 \\
Human Resources & 2 & 1 & \\
Tangible Resources & 1 & & \\
Knowledge and Experience & 2 & & \\
Organizational Culture & and & & \\
\hline
\end{tabular}

Figure 7. The Capabilities and resources of the examined companies

\section{Conclusion}

The companies which are investigated in this study determine their strategic plans considering their own sources in order to survive in a highly competitive environment. The study aims to research how these companies differentiate themselves from the other companies. The data is obtained through semi structured interview. In as much as the companies operate in different industries this condition leads them to take different positioning, because the competiveness in all this industries is very high. In the study, there are two manufacturing companies and one is a construction company. These three companies have different sources. According to the Resource Based Approach study, the resources are used to obtain competitiveness.

The main mutual characteristic of the companies is that all of them operate in Istanbul. The location is a very important advantage to find the most skillful and experienced employees and to follow the most innovative producing ways and to find the network to cooperate or to reach the customers. For instance, in the construction company working with experienced employees also creates an organizational culture in their company and this culture shortens the adaptation period of new beginners. This organizational citizenship behavior increases the productivity of staff. The company still invests for developing working experience to make sure that culture can sustain with their newcomers. The food company emphasizes that the marketing and sales staff have high marketing and sales skills and keeps the highest level of the work by training. The impact of the price guarantee of their system is high. The automotive manufacturing company believes in investing in people and the innovation potential of them. All of the companies work with high know-how. They constitute an organization climate such a learning organization, to retain the innovativeness. The company culture and other "soft" aspects are as critical as hard aspects (bottom line factors) to success. Choy and Suk (2005). The findings suggest the important role that knowledge building. Intellectual property affects the company performance like production processes. Karmasak and Yozgat (2013) assume that the impact of the unique resources and capabilities on the sales turnover, profitability and market share performance is higher in service companies than in manufacturing companies. 
Further areas of research can be conducted to determine the extent to which competencies exist in other organizations. The research has limitations such as subjectivity of the data because the lack of time and limited number of interviewee. Further investigations can provide support through a larger set of observations. This paper aims to present managers to identify the critical variables necessary to attain sustained advantages. It would be useful to determine whether the above also applies to service companies and other locations. Future research is encouraged to apply longitudinal, test and further develop the proposed framework about the relationships between knowledge, competence, and performance.

\section{References}

Acar, A. Z., \& Zehir, C. (2008). Kaynak Tabanlı İşletme Yetenekleri Ölçeği Geliştirilmesi and Doğrulanması, İsletme Fakültesi Dergisi, 8(1), 103-131.

Amit, R., \& Schoemaker, P. J. H. (1993). Strategic assets and organizational rent. Strategic Management Journal, 14(1), 33-46. http://dx.doi.org/10.1002/smj.4250140105

Aşkun, B., \& Bakoğlu, R. (2010). Can innovation be the reason for a long term survival? Journal of Global Strategic Management, 4(2), 113-125.

Bakoğlu, R. (2003). Kaynak bazlı firma teorisi kapsamında değişen rekabet avantajı kavram and anlayışı. I. Ü. İsletme Fakültesi Dergisi, 32(1), 65-76.

Bakoğlu, R. (2004). Strateji and stratejik yönetim kavramlarını yeniden düşünme. Mali Çözüm Dergisi, 67, $155-168$.

Bakoğlu, R. (2010). Çağdaş Stratejik Yönetim. Beta Yayın: 2305, İşletme Ekonomi Dizisi: 415, İstanbul.

Bakoğlu, R., \& Yılmaz, E. (2005). Rekabet avantajı yaratmada tedarik zinciri tasarımı: Mc donald's Türkiye örnegi. Öneri, 6(23), 81-91.

Barney, J. B. (1986a). Organizational culture: Can it be a source of sustained competitive advantage. Academy of Management Review, 11(3), 656-665. http://dx.doi.org/10.5465/AMR.1986.4306261

Barney, J. B. (1986b). Strategic factor markets: expectations, luck and business strategy. Management Science, 32(10), 1231-1241. http://dx.doi.org/10.1287/mnsc.32.10.1231

Barney, J. B. (1991). Firm resources and sustained competitive advantage. Journal of Management, 17(1), 99-120. http://dx.doi.org/10.1177/014920639101700108

Barney, J. B., \& Clark, D. N. (2007). Resource-based theory: Creating and sustaining competitive advantage. Oxford University Press, Oxford.

Choy, C. S., \& Suk, C. Y. (2005). Critical factors in the successful implementation of knowledge management. Journal of Knowledge Management Practice, 6(1).

Collis, D. J., \& Montgomery, C. A. (1995). Competing on resources: Strategy in the 1990s. Harvard Business Review, 73(4), 118-128.

Cool, K., \& Schendel, D. (1988). Performance differences among strategic group members. Strategic Management Journal, 9(3), 207-223. http://dx.doi.org/10.1002/smj.4250090302

Deliorman, R. B., \& Bahar, M. (2009). Örgütsel bağlam paradokslarının güç okulu açısından değerlendirilmesi. Öneri, 8(32), 27-37.

Grant, R. M. (1991). Resource based theory of competitive advantage. California Management Review, 33(3), 114-135. http://dx.doi.org/10.2307/41166664

Kamaşak, R., \& Uğur, Y. (2013). Endüstriyel Faktörler, Benzersiz Kaynaklar Ve Performans İlişkisi: İmalat Ve Hizmet Sektörü İşletmeleri Üzerine Bir Araştirma. Akdeniz University Faculty of Economics \& Administrative Sciences Faculty Journal/Akdeniz Universitesi Iktisadi ve Idari Bilimler Fakultesi Dergisi 13.27

Learned, E. P., Christensen, C. R., Andrews, K. E., \& Guth, W. D. (1965). Business policy: Text and cases. Irwin, Homewood.

Mills, J., Platts, K., \& Bourne, M. (2003). Applying resource-based theory: Methods, outcomes and utility for managers. International Journal of Operations \& Production Management, 23(2), 148-166. http://dx.doi.org/10.1108/01443570310458429

Penrose, E. (1955). Research on the business firm limits to the growth and size of firms. American Economic 
Review, 45(2), 531-543.

Penrose, E. T. (1952). Biological analogies in the theory of the firm. American Economic Review, 42(5), 804-819.

Porter, M. E. (2008). The five competitive forces that shape strategy. Harvard Business Review, 86(1), 78-93.

Prahalad, C. K., \& Hamel, G. (1990). The Core Competence of the Corporation. Harvard Business Review, 68(3), 79-91.

Prahalad, C. K., \& Hamel, G. (1994). Strategy as a field of study: Why search for a new paradigm. Strategic Management Journal, 15, 5-16. http://dx.doi.org/10.1002/smj.4250151002

Schneider, M., \& Lieb, P. (2004). The challenges of teaching strategic management: Working toward succesful inclusion of the resource-based view. Journal of Management Education, 28(2), 170-187. http://dx.doi.org/10.1177/1052562903252646

Valentin, E. K. (2001). SWOT analysis from a resource-based view. Journal of Marketing Theory and Practice, $9(2), 54-69$.

Walsh, P. R. (2005). Dealing with the uncertainties of environmental change by adding scenario planning to the strategy reformulation equation. Management Decision, 43(1), 113-122. http://dx.doi.org/10.1108/00251740510572524

Wernerfelt, B. (1984). A resource-based view of the firm. Strategic Management Journal, 5(2), $171-180$. http://dx.doi.org/10.1002/smj.4250050207

\section{Copyrights}

Copyright for this article is retained by the author(s), with first publication rights granted to the journal.

This is an open-access article distributed under the terms and conditions of the Creative Commons Attribution license (http://creativecommons.org/licenses/by/3.0/). 